\title{
THE HISTORICAL EMBEDEDNESS OF ORGANIZATIONAL PARADOXES: RISK-RELATED RITUALS AND REALITIES IN EMERGENCY MANAGEMENT
}

\author{
Dean Pierides \\ University of Stirling, Scotland \\ d.c.pierides@stir.ac.uk \\ (corresponding author) \\ Stewart Clegg \\ University of Technology Sydney, Australia \\ Universidade Nova de Lisboa, Carcavelos, Portugal \\ Miguel Pina e Cunha \\ Universidade Nova de Lisboa, Carcavelos, Portugal
}

\begin{abstract}
Paradoxes are historically embedded in institutions and organizations. Latent paradoxes pose danger if they become salient; sociological analyses can identify historically embedded latent paradoxes. The emergency management paradox, in which the state invests vast resources, establishing formidable organizational arrangements that rely on knowledge to respond to unanticipated events in advance of their occurrence, even though such events can only ever be known after they occur, is a paradox of this kind. Deploying methodological 'dual integrity' we trace through historical description and sociological conceptualization the institutional and organizational history of the emergency management paradox in Australia, where uncontrollable bushfires are becoming increasingly common, before drawing more general conclusions about how a response to grand challenges, such as climate change, demands an interdisciplinary understanding of the rituals and realities of paradoxes that emerge historically from our collective attempts to handle uncertainty via risk. Our research serves as a warning of the grave consequences that can result from ignoring a paradox's history, whether intentionally or unwittingly.
\end{abstract}

Keywords: Paradox; risk and uncertainty; emergency management; unexpected events; organizational history; dual integrity. 


\section{INTRODUCTION}

Paradoxical tensions in organizational systems "may remain latent — dormant, unperceived, or ignored - until environmental factors or cognitive efforts" make them salient (Smith \& Lewis, 2011, p. 390). While recent research has underscored the ontology of paradoxes (Hahn \& Knight, 2019; Schad \& Bansal, 2018) in preference to empirical cases, we turn to empirical history and concepts that refer to empirical problems. In case of crises such as the 2020 COVID-19 pandemic, tensions unfolded because sources of insecurity arose not encompassed by the scale and scope of existing risk knowledge practices or routines. Political sociologists refer to this condition as a "security paradox", arising from multiple and conflicting logics (Kessler \& Daase, 2008), many of which pre-date the rise of risk management (as described by Power, 2007). Our aim is to understand an empirical case in which this security paradox became not only latent but also invisible, from the point of view of risk.

To do this, we rely on the following structure. First, we summarize what we refer to as the emergency management paradox, that arises through the state investing vast resources and establishing formidable organizational arrangements that rely on knowledge to respond to unanticipated events in advance of their occurrence, even though such events can only ever be known after they occur. Second, we draw on methodological resources from historical organization studies to develop our work (Maclean, Harvey, \& Clegg, 2016). Finally, we discuss the relationship between uncertainty and organizational paradox and the role of rituals in this relationship as well as how a paradox focus can inform understanding of 
governmental shifts in the organization of security. Identifying a tension between anthropological recourse to ritual to ward off uncertainty and the realities of emergency management, we conclude with a comment on the consequences of our research for the ongoing fight to protect populations from COVID-19 as well as the equally urgent need to respond to climate change. Through a historical-empirical description of how risk thinking in particular is dangerously ignorant about the emergency management paradox, we are able to conclude that the historical embeddedness of organizational paradoxes renders them latent and invisible in the present. The task of the sociological imagination is to make the processes of latency available for scrutiny and reform.

\section{THE EMERGENCY MANAGEMENT PARADOX}

Regulating, ordering, limiting and bounding uncertainty has been a canonical concern throughout organization studies' history of ideas (Clegg, 2010). How organizational scholars relate to uncertainty has relatively recently become refracted through different disciplinary understandings of risk, including organizational scholarship (Hardy et al., 2020) that understands risk, how risk objects are socially constructed and how they are organized (e.g. Hardy \& Maguire, 2016, 2020; Maguire \& Hardy, 2013). Important risk-related paradoxes emerge from tensions between the present and the histories from which risk management emerged. To study this tension between the past and the present, we focus on the institutions and organizations that are tasked with managing and organizing emergencies that result from unknowable and unpredictable events. In the face of such events we ask how does organizational action designed to cope with these 'unknown unknowns' become paradoxical? 
To make sense of this paradoxicality in an intelligible way, we describe how governmental apparatuses for managing risk take shape (e.g. Collier \& Lakoff, 2008, 2015; Deville \& Guggenheim, 2018; Deville, Guggenheim, \& Hrdličková, 2014). Agencies collectively known as emergency management organizations, for example FEMA and all of its arms in the United States or, in the United Kingdom, the Cabinet Office Briefing Rooms, commonly known as 'COBRA' and the range of 'blue light services', are government institutions responsible for managing catastrophic risks for people and property. Emergency management presumes the capacity to anticipate and act on events whose occurrence is unpredictable because it is based on knowledge about occurrences that cannot exist; thus, emergency management prefigures events whose scope cannot be known accurately a priori. The events being prepared for cannot, ex vi termini, be anticipated in where and when and with what consequences they will occur. Hence, an initial question is why invest in managing something that is by definition unknowable?

To deal with this conjuncture of possibilities, contemporary emergency managers use a fourstage structure of mitigation, preparedness, response and recovery, allowing them to partition work into what needs to be done before, during and after an emergency. During the response phase, attending to events that evade extant meaning (Cunha, Clegg, \& Kamoche, 2006), an especially consequential paradox occurs: the "emergency management paradox". To understand the contemporary emergency management paradox, we analyse the historical conditions under which emergency management organizations developed. 


\section{METHODOLOGICAL APPROACH}

From a historical perspective, methodological integrity demands command of data and sources, often to an extent seemingly more elaborated than the typical organization studies case study. ${ }^{i}$ From the organization studies perspective methodological integrity requires that historical narration becomes theoretically conceptualized. Elaborating historical conditions in concert with conceptualization prepares the twin foundations for "dual integrity" (Clegg et al., 2021; Maclean, et al., 2016). Methodological dual integrity entails doing both (Maclean et al, 2016) in which deep immersion in historical data, requiring skill in a narrative approach, combines with a degree of conceptualization alien to many historians; thus, dual integrity employs historical data about institutions and organizations and combines this with sociological conceptualization, in this case of analyses of risk and security (Clegg, et al., 2021). For the former we construct a historical narrative, for the latter we draw most notably on concepts from the social study of risk and uncertainty to discuss emergency management organizations (esp. Amoore \& de Goede, 2008; Dean, 2010). We connect the historical and the conceptual using the key notion of paradox.

The unfolding of paradoxes historically sees them as based on layers of previous decisions and structures. Understanding the tensions generated as a consequence of history allows us to consider, comparatively, both the origins of paradoxes and a reflexive understanding of the limits of paradox theory. As Smith et al. $(2019$, p. 4) have noted, there are "paradoxes of paradox" that can be described as "contradictory, yet interdependent perspectives on paradox enveloped in the core theoretical assumptions". We explain how practices, developed and 
institutionalized over long periods of time, can render organizational paradoxes latent. The insights afforded from studying paradoxes historically can hardly be overstated; sociologists of organization need to consider the disastrous consequences for practice of conceptually ignoring the invisible tensions that we will describe between past-present, visible-invisible, unexpectedness-preparedness.

Emergency management organizations operate in life-or-death extreme contexts and in so doing "provide a unique platform for the study of hard-to-get-at organizational phenomena" (Hällgren, Rouleau, \& de Rond, 2018, p. 112). Before, during and after a disaster, emergency management organizations are responsible for addressing the full range of organizational surprises (Cunha, et al., 2006). These organizations have changed not only across their lifespan but also through prior events that shaped the reasoning that justified their establishment in the first instance. By definition, emergency management organizations are designed to plan for the unexpected, giving rise to nested and embedded paradoxes (Schad \& Bansal, 2018).

Emergency management organizations, designed to deal with risk and uncertainty, all have unique histories even when developing similar organizational tools and instruments. Among these are risk devices (e.g. Callon, Millo, \& Muniesa, 2007), risk practices (e.g. Power, 2007), risk routines (e.g. Power, 2016), risk technologies (e.g. Perrow, 1984), the social construction and translation of risk objects (e.g. Hardy \& Maguire, 2020; Hilgartner, 1992), risk communications (e.g. van Loon, 2014), riskwork (Power, 2016), etc. The constellation of organizational risk instruments strive to encompass past learning while envisaging a future of 
risk essentially unknowable as to how, where, why and when what will occur (Foucault, 1986). Traces of the past in its present accounting are oriented towards future unknowable risks, a temporal mangling, generating paradoxes. Understanding risk-related paradoxes requires a different starting point from prima facie conceptions for analysis of risk. Institutional and organizational histories frame the limits of experience and imagination in managing risk. The limits of imagination in our case are framed by Australian history.

\section{EMERGENCY MANAGEMENT'S HISTORICAL EMBEDEDNESS}

The military and civil defence origins of Australian emergency management

Australian emergency management organizations emerged in the early twentieth century, drawing on early foundations established in the United States, the United Kingdom and across the British Empire. Emergency management, not being constitutionally legislated elsewhere, is a reserve power of the Australian Commonwealth government. Emergencies that result from unexpected enemy attack, bushfires, flooded rivers or a pandemic do not respect constitutional boundaries. The ad hoc occurrence of disasters often requires the Australian government to modify arrangements between federal, state and local responsibilities to manage specific emergencies, prompting legislative changes. States and territories hold responsibility for organizing local responses to emergencies although, in the context of emergency management, the structural relationship between federal and state governments was constantly changing, as Australia experimented with different ways of adopting policy models from the metropole. 
Civil defence directorates were first created at the State and Territory level in the late 1930s. At this time the importance of being able to cope with "all emergencies" was signalled; however, given the backdrop of world wars, attention was directed almost exclusively toward preparation for air raids. At the outbreak of the Second World War, Australia established air raid precautions adopting the model of the British Civil Defence Act of 1939. Wardens were appointed across the country, adopting British handbooks, pamphlets and memoranda. Many of the air raid wardens were men of military experience but too old to be sent to war. Most Australian defence preparations structurally dovetailed with those of Great Britain, reflecting its dominion status (e.g. Wigley, 1977). Defence agendas in the Empire were set at Imperial Conferences during full plenary sessions on defence and foreign affairs. Imperial Conferences provided the opportunity for Dominion defence representatives to interpret and meet the requests of the British government (McCarthy, 1971, p. 21). The 1930 Imperial Conference pushed for a standard War Book throughout the Commonwealth. Australia established a special section of the Department of Defence devoted to this task (Jones, 1995a, p. 32). In August 1936 through to September 1938 planning was directed largely toward the coordination of state infrastructures during gas attack to protect the major cities' civil population. Responsibilities for coordination were clear while financial responsibility was not, an ongoing issue that Hasluck (1952) argues characterizes the Australian case.

In March 1939 it was decided that responsibility for emergencies would lie with each state, with co-ordination remaining at the federal level. A new section of the Department of Defence was created to correspond directly with responsible officers from the states. State- 
level civil defence turned out to be more difficult to coordinate than initially imagined. The proposal that organization of air raid precautions should cope with any national emergency was accepted. For most of 1939, the structure of emergency organizations developed in different ways from one place to another.

On 3 September 1939, Prime Minister Robert Menzies announced to the Australian people that they too had joined Great Britain at war with Germany. At first, Australian Imperial Forces and volunteer forces were mobilized and sent abroad to support Britain; aside from rising costs and increasing unemployment, the risks of war were not experienced until the Japanese bombing of Darwin in February 1942. By the mid-1940s, air raid precautions and their military organization had already become institutionalized, despite media representations of disorganization (see Vardenga, 1978). Suggestions were made for the "[r]e-establishment of skeleton Air Raid Precaution services recruited from civilian volunteers" (The Sydney Morning Herald, 1949). Civil defence organizations continued to develop roughly along already established military lines.

A preoccupation for most of the 1950s was noted by Jones (1995a, p. 36) as "a lack of clarity in what civil defence plans and programs were required, and a potential for conflict in the effective management of civil defence measures". There was continued uncertainty about where the responsibility for civil defence resided after the war ended (see Jones, 1995b). The federal government's primary responsibility was to coordinate and advise the states. The responsibility was uncertain enough to be shifted around, for instance from the Civil Defence and State Cooperation section to the Department of Home Security. In the early 1950s, civil 
defence was located in the Department of the Interior, despite differences of opinion between the Minister and the Prime Minister about where responsibility should lie (Department of Defence, 1983, p. 113).

In the early 1950s, professionalization (Meyer \& Bromley, 2013) of civil defence education occurred as a mechanism for institutionalizing legitimacy for centres for civil defence organization in the event of nuclear threat. The Commonwealth Civil Defence School was created in 1956 for training personnel from the recently established state-level Civil Defence Committees. The government-based Civil Defence School changed names a number of times (National Emergency Services College, Australian Counter Disaster College, Institute of Emergency Services), eventually becoming the Australian Emergency Management Institute. Initially created for "the protection of the civil population from enemy raids, coastal raids, atomic attack and biological warfare" (The Age, 1955) it later conducted "a range of activities designed to improve Australia's capability to mitigate, manage and recover from disasters" (Australian Emergency Management Institute, 2013). The institute relocated to Canberra in 2015 where it operated "to build capability through collaboration, innovation and education" (EMA-AEMI, 2015). The present-day parent organization is the Australian Institute for Disaster Resilience.

By the middle of the twentieth century emergency management was recognizably an institutional field, populated by complex organizations with multiple functions. A common professional purpose defined different nations' emergency management organizations: “to ensure the maintenance and well-being of a sovereign society" (Britton, 2006, p. 347). 
Organizational scripts were rooted in military planning, so emergencies were viewed as extensions of "enemy attack" scenarios to be addressed with command and control structures. However, as Dynes (1994) argues, military analogies had limitations. If emergency management was to be organized more appropriately the military model would need to be overcome. The next section shows that the immediate changes proposed and established in response to this problem continued to uphold the sovereign goal under which the organizations were originally established.

\section{Organizational response to natural disasters}

A definitive shift in Australian emergency management occurred after a series of severe natural disasters between the late 1960s and early 1970s. These came to be known as the “disaster years", when civil defence reoriented from war-related dangers toward threats from natural disasters. The Tasmanian Black Tuesday bushfires (7 February 1967), the Brisbane flood (January 1974) and Cyclone Tracy (25 December 1974) caused widespread and significant damage. While each disaster unfolded in different ways, their impact shaped Australian emergency management at all levels. On Black Tuesday, 110 separate fires were recorded in the South of Tasmania in which 62 people died, many more were injured and left homeless, 1,293 homes were destroyed and over half a million acres of land burned. The Tasmanian fires signalled to Australia that the Commonwealth government could not defer all responsibility for disaster prevention to the states. 
The incoming Labor government in 1972 established a new political agenda: "Labor believes that the crippling effects of natural disasters like droughts, floods, fires and cyclones must be minimized. We shall establish a national disaster organization to handle these crises with speed and efficiency" (Whitlam, 1972, p. 20). In 1974, the functions of the Australian Civil Defence Directorate were absorbed into a new organization called the Natural Disasters Organization (NDO). The NDO was the result of redesigning the Directorate to be responsible for natural disasters without sacrificing the capacity to defend against enemy attack. The NDO was barely ten months old when Cyclone Tracy struck Darwin with devastating effect. The Commonwealth government was formally responsible for providing support in a territory rather than a state. In the words of the then Director of Operations and Plans "the only sort of models that we had" were "the old civil defence models ... based on loose concepts that when an event happened, we rushed out and ran it-which of course we didn't" (Jones, 2005, pp. 55-56). Cyclone Tracy was not only a test of these new NDO arrangements but a "baptism of fire" (Hodges, 1999, p. 14) marking the conversion of statelevel civil defence bodies to Emergency Services. The states and territories established emergency services through various acts that legislated the role of various disaster and civil defence organizations based on local volunteerism.

The Whitlam Labor government (1972-5), expanded the use of Specific Purpose Payments (SPPs), raised under section 96 of the Constitution, to grant financial assistance to states as needs arose. SPPs shaped how emergency management was financed. After Cyclone Tracy, states received assistance to manage emergencies and disasters through SPPs, reflecting a 
"traditional emergency management approach, which is in the area of response and relief" (Dwyer, 2006, p. 44). In 1975, the Australian Red Cross Society created the Red Cross Disaster Services Department and the National Disaster Relief Committee, facilitating standardization by nationalizing coordination under the banner of preparedness and training. The expansion of organizations in relation to disasters characterizes the period that sits roughly between Cyclone Tracy in 1974 and the early 2000s. During this period, responsibility for different kinds of threats converged as the core tasks of emergency management organizations divided in terms of disaster-related responsibilities.

Emergency management legislation developed from the early 1980s onwards and the range of organizations and actors, roles and positions, significantly expanded, as did the role of formal knowledge. Professionalization and institutionalization were oriented almost exclusively to natural disasters in spite of the convergence of civil defence and natural disaster problems under a common umbrella of emergency management. Jones (1995a) argued that the civil defence domain was being evacuated by emergency management organizations, reducing the number of social positions and tacit knowledge.

\section{CONTEMPORARY EMERGENCY MANAGEMENT}

\section{Economic reform}

Continuing professionalization through education and organization characterizes contemporary emergency management. In the mid-1980s the Australian Inter-Service Incident Management System (AIIMS) was developed, with the aim of becoming a "robust 
incident management system that will enable the seamless integration of activities and resources of multiple agencies when applied to the resolution of any emergency situation" (Australasian Fire Authority Council, 2004, p. i). A management framework establishing authorities at different levels and between different levels was created in an attempt to centralize control of highly decentralized government arrangements. While states and territories were responsible for the protection of people and property, the ultimate locus of control for AIIMS was federal.

For a short period in the late 1980s organizationally centralized control was aided further by the establishment of emergency management education located exclusively in universities. Collaborations formed between state-level emergency services and universities in the early 1990s, creating emergency management education programs providing various forms of standardized certification, such as the Commonwealth counter disaster concepts and principles (Natural Disasters Organisation, 1989). The concepts underpinning this were: (1) an "all-hazards" approach; (2) a "comprehensive" approach; (3) an "all-agencies" or “integrated" approach and, (4) a "prepared community" approach. Much of this terminology came to dominate later efforts to "improve" emergency management. In particular, the principles refer to hazard analysis, organization, information and, not least, "command, control and co-ordination". Three institutional and organizational shifts were occurring at the time. First, the naming of the EMA reflected its new functions (from response to emergency management). Second, significant numbers of military staff were reduced, with EMA becoming by 1999 a wholly civilian staffed organization. Third, high level emergency 
managers began to conceive of the 'field' of emergency management. Fourth, a simple vertical chain of command was being replaced by a network of interrelated organizations.

\section{Comprehensive emergency management based on PPPR}

Emergency Management Australia adopted four key principles that aligned with the broader impetus to rationalize government along economic lines (Pusey, 1991): a comprehensive approach; an all hazards approach; an all agencies approach and a prepared community approach. State emergency management organizations began to adopt risk management protocols. ${ }^{\text {ii }}$ Salter (1997, p. 60) notes a "paradigm shift from extreme events to a focus on vulnerability and the management of social impact; from hazard to risk", in a basic architecture adopting a comprehensive approach or Prevention (previously Mitigation), Preparedness, Response and Recovery (or PPPR) approach, developed by the United States National Governors' Association (1979). As the U.S. State Governors' Association model was translated to Australian emergency managers through training programs, so too the adoption of this model by Australian emergency management was translated for Asian countries through various publications (see Carter, 1991), indicating the development of an international professional field of shared knowledge.

Underlying the approach is the familiar plan, do, check, act model (Deming, 2000). Prior organizational scripts did not entirely replace subsequent ones but there was a continuation of standardization (e.g. the international diffusion of standards) amplified by broader economic reforms. Managerialism became "a fundamental leitmotif” for reform by assuming that 
"efficiency in the public services can be achieved by simulating a business situation, by adapting the methods and practices of the private sector to the public services" (Bogdanor, 2001, p. 291; see also du Gay, 2006). Policy was shifting from "an internal agency focus to a community-centred focus - a shift away from delivering a limited range of services (usually response based) to more intelligent resource allocation based on risks - business-like management and outcome based performance" (Cronstedt, 2002, p. 11). In a risk-driven approach the "selection of treatments should be based on criteria founded on efficiency, effectiveness and economy" (Cronstedt, 2002, p. 12). The desire was to focus on "the broader context of the ongoing everyday life of the community" (Gabriel, 2003, p. 75) wherein risk is to be found, rather than taking responsibility for and responding to emergencies, as was previously the case. PPPR, rather than assuming responsibility for hazards was premised on the responsibility of members of the public taking care of their vulnerabilities.

The comprehensive approach was enshrined as one of four key principles of Emergency Management Australia. The shift of responsibility was from government agencies to communities which, together with the priority given to managerial criteria, meant that the responsibility of agencies to respond to events and emergencies was not entirely eradicated. However, responding to emergencies became mission-subordinated to the identification and treatment of risks. According to the Australia/New Zealand Standard ISO 31000:2009, risk is "the effect of uncertainty on objectives". With the shift from responding to hazards to managing risk by organizing for security, the conceptual framing constituting the emergency management paradox was established as based on managing routines. As we shall argue, 
routines can become rituals that, when they fail, call forth symbolic and performative figures to minimize the grounds that failed.

\section{DISCUSSION}

The introduction of risk management as an organizational solution to problems happened only recently. Historically, organizations in this field were clearly driven by a sovereign task: to defend the members of a territorial population and their property against hazard when it occurred. Contemporary organizational preparedness routines are guided by modes of organizing security. Rehearsing routines became the rationale for organizational existence and continuity in the face of imponderable questions of where, when, how and why what natural disaster might strike. Different approaches to precaution came to constitute layers in the tectonic plates of history. ${ }^{\text {iii }}$ The tensions between these layers generate paradoxes between practicing routines and responding to hazardous and unknown risks that routines can render invisible. In the absence of a catastrophic event the paradox remains hidden (Figure 1).

\section{FIGURE 1 ABOUT HERE}

Figure 1: The emergency management paradox

Figure 1 depicts how the emergency management paradox is a consequence of the management of risk becoming explicit as modes of organizing security become latent. The paradox emerges from the tension between latent sovereignty (defend and protect) and explicit rationalism (risk management). The emergency management paradox is invisible 
from the point of view of risk alone but remains identifiable from an analysis of the history of present organizations.

Our discussion will focus on three things: how we might think about uncertainty, risk and security in the study of organizational paradox; the necessary functional yet paradoxical role of rituals in resolving the relation of these terms in practice, as well as the contribution that studies of organizational paradox can make to understanding security.

\section{Organizing security in the face of uncertainty in emergency risk management}

An illusion of control was vested in risk management approaches introduced by governments in the 1990s. These reforms were initially designed to reduce economic costs. Continued investment in emergency management as a way of organizing security was justified by the potential of unknowable yet potentially annihilating future events for which states should be organizationally prepared. The question of how much or how little government intervention this involved was constituted as an under-specified but ongoing political-economic reform or “change” project (du Gay \& Vikkelsø, 2012). Generalized risks should be managed and when a catastrophic bushfire, pandemic or financial crisis arrived unexpectedly, wreaking harm, experts will subsequently dissect it by striving to posit how and why putative control over nature, health and prosperity established beforehand did not work as well as strategically promoted. Risk management thus evolves in response to a constant cycle of uncertain events that paradoxically confound its organized pretensions to knowing. 
Earlier practices aimed at protecting people and property through sovereign authority rather than attempting to manage risk. Beck (1992) initially argued that late modern societies exhibit a tendency toward treating an ever-growing number of unintended consequences of modernity as risks, allowing these societies and their members to then develop knowledge and technologies to curb or eliminate excesses they created. Faced with the aftermath of a post-9/11 world, Beck (2002, p. 41) would later revise this position to argue that in politics, law, science, technology, economy and everyday life, there is an unacknowledged tendency to "feign control over the uncontrollable". Beck argues something both paradoxical and opaque is happening in the risk society. There is a need to go beyond analysis of the modes by which risk is organized (Hardy \& Maguire, 2016), to identify what is being expected of organizations that are tasked with controlling uncontrollable uncertainty beyond risk management.

Stated positively, the relationship between uncertainty and organizational paradoxes can form in multiple epistemological and ontological ways. When organizations and societies are conceived as the rational products of modernity, anything that is a potential source of uncertainty poses a challenge. Within modernity, uncertainty is conceived as the outer limits of rationality. A “demon" against which organization and its theories are directed, uncertainty is seen to be a purely epistemological problem (Tsoukas, 2005). Uncertainty, however, will always be more than what knowledge can make of it (see: Pierides \& Woodman, 2012). Since uncertainty means a lack of knowledge in most organizational analyses, this lack is an Achille's heel for modern organizations: events, despite persistent efforts to make things 
certain through the organization of risk, can always unsettle what is known to be known and what is not known to be unknown. From the point of view of rational organization, such paradoxes of modernity are a necessary product of modernity itself, to which the project of modernity demands a response (Badham, 2019) and organizational paradox studies show the many forms that response can take.

Risk-related paradoxes become apparent only when the lifespan of organizations responsible for managing emergencies on behalf of the state is investigated; risk management routines, while adaptable, can prove inadequate when confronted by conditions of risk characterized by indeterminacy. At the time that risk-related routines are enacted the momentum associated with the indeterminacy and position of risk cannot be calculated precisely. Paradoxically, routines overwhelm appreciation of the indeterminacy of novel conditions of risk; routines lag risks whose conditions of possibility are least appreciated, precisely because the problem with the future is that it is yet to happen.

Risk management is an instrument that emergency managers use to govern on behalf of the state. When governing for security or preparing for the unknown it is catastrophic events that signal crisis. Therefore, the emergency paradox only becomes visible to organizations when things go terribly wrong during "loss of meaning" events. According to Cunha, et al. (2006) loss of meaning events produce wholly unexpected issues and processes. What distinguishes them from other surprises is that they are absent from the domain of knowledge. Knowledge can only apprehend loss of meaning events after they occur, which gives them the strange property of being knowable only in their past. Future such events are unknown. The 
consequences can be a matter of life and death. These surprises bind unanticipated events together with rehearsed routines when they do occur, in which the domain of uncertainty claims them as its own; as Knight (1921) argued, this makes surprises unknowable, unpredictable and uninsurable. One cannot know when a surprise will occur and it is impossible to know what its content will be in advance of its occurrence. Cunha, et al. (2006) give the archetypal example of the $9 / 11$ attacks on the Twin Towers as an instance of this kind of event.

When the 2009 Black Saturday bushfires occurred in the south-eastern part of Australia, 173 people died as Victorian government agencies struggled to deal with organizational arrangements that became untenable. Once the event faded into memory and the "retrospective" mode of organizing risk ensued (Hardy, et al., 2020), not all the findings of subsequent commissions of inquiry were implemented (cf. Dwyer \& Hardy, 2016; Dwyer, Hardy, \& Maguire, in press). As one academic commentator from the ecology and forest sciences discipline wrote, "[t]he propensity for inquiries has had the perverse effect of making bushfire management less effective and efficient than it should be" (Tolhurst, 2019) because such inquiries typically apportion responsibilities rather than accrue learning; moreover, many of their recommendations remain unimplemented (Parliament of Victoria, 2010).

In organization theory terms, the literature that has attempted to analyse institutional incompatibility either assumes that tensions get resolved within logic (e.g. Greenwood, Suddaby, \& Hinings, 2002; Thornton, Ocasio, \& Lounsbury, 2012) or that human actors are 
aware of this incompatibility and somehow able to respond to it logically (e.g. Reay \& Hinings, 2009). At the root of this emphasis on logic is "the modern dream of the knowledgeable actor who, freed from the shackles of ignorance, can think for himself/herself and can undertake informed, responsible action" (Tsoukas, 1997). Loss of meaning events are the most coveted target for control yet, by definition, they are most unknowable, thus producing an absurd desire for knowing the unknowable which can make routines ridiculously inappropriate.

Events that are unknowable reside outside the envelope of both institutionalized knowledge and intentional planning; as noted by Cunha, et al. (2006), they are similar to what Weick (1993) described as cosmology episodes. According to Weick (1993, p. 633), everyday assumptions that conceive of the universe as a rational, orderly system can be completely disrupted during these episodes, thus demonstrating that cosmological problems "are not just the handiwork of philosophers". The paradoxes that emerge during loss of meaning events can be of a cosmological order and what makes these particularly interesting for scholars of organization is that they rely on deeply held assumptions that make the cosmos rational; in other words, events may potentially confound rational expectations.

\section{The relationship between uncertainty and organizational paradoxes}

Events, more so catastrophic events, can "visibilize" the invisible (Tuckermann, 2019). The 2019-2020 summer in Australia started with bushfires in September, before summer had even officially started. By late-January, despite substantial rainfall, they had yet to abate. At least 
33 human lives were directly extinguished (additional deaths were reported from secondary effects, such as asthma attacks), along with an estimated one billion non-human lives, over three thousand five hundred homes and almost six thousand sheds, barns, and other nonresidential buildings destroyed, across at least one hundred and eighty thousand square kilometres of territory, larger than the total size of Greece; species survival was threatened as the fire consumes and destroyed habitats, with over a million animals lost and a pall of smoke polluting the inhabitants of cities safe from the fires such as Canberra, Melbourne, and Sydney. 2019 was the hottest and the driest year on record with Australia the canary in the globally warming planet.

The warming planet's effects on its most arid continent are making the reality of a warming continent highly visible. As the invisible reality of the warming, drying continent becomes visible in fires the extent and magnitude of which were unprecedented, emergency organizations struggled to bring order to the chaos that ensues. On the part of the current federal government, there is climate change denial slowly acceding to a grudging acceptance that various strategies from the past, such as hazard reduction, will better plan for the new unknown unknowns, despite academic advice to the contrary that it will only intensify fires (Lamont \& He, 2020). Emissions reduction at the federal level that does not change the economic and employment status quo remains government policy. At every stage, recalcitrantly, the federal government has sought to position the bushfire issues as a state responsibility from which it is federally absolved. The response phase in which this has taken place characterizes a growing breach between federal governmentality and the response work 
that emergency management organizations undertake. The response phase, or what Hardy, et al. (2020) refer to as the "real-time" mode of risk organizing, nevertheless remains an important and indispensable part of the core responsibilities of emergency management.

Although global warming is making the incidence of bushfires more likely, it is impossible to know the future in advance of its occurrence. In the face of this impossibility an elaborate calculative risk management technology developed to posit future possibilities. On the basis of these anticipatory outputs organizational decisions ensued. What transpires are standard sequences of activities involving organizational gestures and routines, embedded in words and material objects, performed according to set sequences. These are characterized by formalism, the adoption of standards, rule-governance and anticipatory performance of rehearsed routines as talismans against contingent but unknown events. In the day-to-day contemporary practices of emergency managers, the grounds of organization have seen the prior sovereign goal of protecting the members of a territorial population and their property be subordinated to the organizationally routine identification and treatment of risks. Risk technologies introduce anticipation as the goal to be achieved, even though it is not achievable because the future can never be known. It might seem paradoxical to know how an organization can manage to manage what an organization does not know will happen, where it does not know it will happen, when it does not know what will happen. What could legitimate the performative organization that this ensures?

Rituals and realities of organizational paradox 
Organizational legitimation of emergency management services is increasingly premised on a risk management framework in which planning for unknown unknowns can be contained. The organizational framework is combined with media vesting of key symbolic actors with an almost sacred significance when the unknown unknowns transpire, such as volunteer firefighters fighting infernos heroically and remorselessly. The warming world ensures that escalating risk vests in past organizational routines having a diminishing function, momentarily resolved in performances by volunteer fire fighters and emergency managers, as symbolic actors. Between performances, the routines are maintained to ward off what will always return, when and where one cannot tell. Similar rituals occur in other contexts. In the UK, in the face of COVID-19, weekly public applause was collectively organized to honour key workers whose media coverage created similar ritual significance.

Organizations and actors must be seen not just in the immediacy of the risk-dominated present moment but also in historical context. Any present environment is made up of the effects of previous organizations, shaping social responses to that to which they attend. In day-to-day contemporary practices of emergency managers, the prior sovereign goal of protecting the security of life and property is now subordinated to focusing on the organizational identification and treatment of risks. Risk technologies introduce anticipation as the goal to be achieved, even though it is not achievable because the future can never be known. The sovereign goal of ensuring security remains a residue in organizational practices.

The paradoxical condition characteristic of contemporary emergency management organizations is that they ward off the unknown through ritual in ways that are strikingly 
similar to anthropological accounts, for example, of the Azande (Evans-Pritchard, 1937). Ritual foregrounds key figures. Any figure, necessarily, then operates against a context or ground. The figure grabs our attention while the "ground" supports or contextualizes a situation, usually as an area of inattention (Douglas, 2001). Both figure and ground are equally important in understanding the full meaning of a situation. That which is perceived depends on that which is obscured in order to focus perception (Douglas, 1982). What is foregrounded is performing in the theatre of events (Islam, 2016), especially in the most prevalent area of Australian risk, that of bushfires. It is there that we find the highly symbolic figures, the first responders known in Australian parlance as "fireys", the volunteer fire fighters on the frontline of bushfire responses. The fireys play the key role of being figures acting in the face of unknowability. When unknown unknown events, such as bushfires occur, the fireys play a symbolic and figurative role in dramatically dealing with the uncertainty that ensues, obscuring organization in its current form, its resources and rehearsed routines behind these actors. ${ }^{\text {iv }}$ The state-based and volunteer basis of the emergency services, however, is increasingly inadequate to a world of changed and extreme risk and events. ${ }^{\mathrm{v}}$ Based on our analysis of the emergency management paradox it would be an error to think that sophisticated risk mapping and management technologies and centralized state control centres are rituals that, in substance, are any different from those of the fireys.

The emergency management paradox produces two kinds of ritual to ward off the threat of the unknown; one organizational, the other figurative. When the unexpected occurs then there are symbolic figures on hand to obscure the paradoxical ground of their organization. First, 
the routines of professional emergency management organizations that become ritual; second, the figurative symbolic role that is played by the frontline firefighting volunteers in responding. The frequency of emergencies caused by bushfires is increasing and they are happening earlier and more intensely as the climate heats and dries the continent of Australia. Organizationally, state-based emergency organizations staffed by volunteers are the legacy first responders. These symbolic figures hold a sacred place in the secular rituals of emergency fire services under increasing pressure as the length and intensity of the fire season expands as the climate heats, dries and burns the terrain.

We have identified the paradoxical grounds as the state investing vast resources in establishing formidable organizational arrangements that rely on knowledge to address unknowable events in advance of their occurrence, even though these events can only ever be known after they occur. We asked, in the face of unknowable and unpredictable events how is organizational legitimation of organizations designed to cope with these "unknown unknowns"? Our answer is that legitimation is produced through organizational routines whose legitimacy the changing climate is eroding as the intensity, ferocity and frequency of bushfires itself intensifies and the routines become less capable of coping with extreme events. Increasingly, more global and less local political action is called for, with communities becoming gradually more aware of this as Australia burns and federal government in Canberra fiddles and fudges facts (Clegg, 2020; Heikkurinen et al., 2019). As the world unfolds and new risks emerge, new forms of balance are required. 
As we write, the implications are even starker. The emergency management paradox arises because governments introduced risk management practices on the back of new public management reforms; in so doing they minimized the sovereign mandate of these organizations to protect lives. During a major disaster such as the outbreak of COVID-19, governments become alert to the fact that this sovereign mandate does not legally or socially disappear. The mandate remains limited in its applicability inside the paradox because the risk-based logic and its associated practices of risk management kick in when events occur. The paradox is then laid bare.

Differing national responses to COVID-19 underscore the practical significance of understanding latent paradoxes before they become salient. In some countries, state and government agencies prioritized public health, whereas in other countries leaders' attention was directed more towards economic markers of employment, business activity and the share market. The consequence of these different choices was that more citizens from some countries focused on the economy have died, relative to others in countries substantively focused on public health. The paradox that constitutes differing governmental responses of this kind remains latent until a disaster, such as the pandemic, occurs. The emergency management paradox saw the initial stress in some countries being "herd immunity" and "keeping the economy running" as responses to COVID-19. The significance of such paradoxes continues to be tragically and spectacularly on display, as we write, amidst the outbreak and unfolding consequences of COVID-19. 
An initial approach aimed at managing risks via modelling, perforce, could not ignore the sovereign goal of protecting the lives of territorial populations at any cost. Initial decisions were made on the basis of a risk calculus; it is because of this that multiple governments failed to respond adequately to the coronavirus, leading to a global pandemic. Some of these governments changed course, buckling under public pressure in the face of mass contagion and mortality; others sought refuge from responsibility in confusion. Risk calculations contained within them an implicit approach that would "let some vulnerable people die" in the interests of a national economy stretched to its limits by prior policies of a minimal state. Such an approach should not be acceptable from the point of view of the state's managers, its people or any organization charged with responding. Yet, even after these approaches came under public pressure for being unacceptable, government shifted rhetoric to the imperative of calculating and mitigating risk through management that balanced individual life and health against national wealth. If anything, recourse to routine risk management has intensified. The emergency management paradox is being re-embedded by funnelling everything through risk and unless attention is drawn to this, it will once again remain latent until the next event occurs.

\section{CONCLUSION}

All 'organizations are complex structures-in-motion that are best conceptualized as historically constituted entities' (Clegg, 1981, p. 545). Paradoxes are a product of the accumulation of historical layers, as if written in a palimpsest in which the past is not buried in time but remains active in the shaping of the present (Cunha et al., 2015). We therefore 
contribute to the debate on interdisciplinary views of paradox by highlighting the relevance of historical knowledge and show how to use historical organization studies (Clegg, et al., 2021; Maclean, et al., 2016), not only to understand the past but also to understand how paradoxes are embedded in it. Paradoxes emerge in specific circumstances and to understand them, scholars need to scrutinize their historical becoming and show how their past still reverberates in their present, expressing the historical embeddedness of paradoxes.

\section{ACKNOWLEDGMENTS}

The research on which this manuscript is based was initially supported by an Australian Postgraduate Award and has benefited substantially from the careful guidance of Graham Sewell. Subsequent revisions to the manuscript have been further guided by excellent editorial comments from Rebecca Bednarek and Wendy Smith. We have been fortunate to have had their contributions.

\section{REFERENCES}

Amoore, L., \& de Goede, M. (2008). Risk and the war on terror. London: Routledge.

Australasian Fire Authority Council. (2004). The Australasian Inter-service Incident Management System $^{\mathrm{TM}}$ (3rd ed.). East Melbourne: AFAC Limited.

Australian Emergency Management Institute. (2013). Pages - Australian Emergency Management Institute. Retrieved 6 April, 2013, from http://www.em.gov.au/Education/Pages/default.aspx

Badham, R. (2019). Reflections on the paradoxes of modernity. In W. K. Smith, M. W. Lewis, P. Jarzabkowski \& A. Langley (Eds.), The Oxford handbook of organizational paradox (pp. 277-295). Oxford: Oxford University Press.

Beck, U. (1992). Risk society: towards a new modernity. London: Sage. 
Beck, U. (2002). The Terrorist Threat: World Risk Society Revisited. Theory, Culture \& Society, 19(4), 39-55.

Bogdanor, V. (2001). Civil Service Reform: A Critique. The Political Quarterly, 72(3), 291299.

Britton, N. R. (2006). National planning and response: National systems. In H. Rodriguez, E. L. Quarantelli \& R. R. Dynes (Eds.), Handbook of disaster research (pp. 347-367). New York: Springer.

Callon, M., Millo, Y., \& Muniesa, F. (2007). Market devices. Malden: Blackwell Publishing.

Carter, N. (1991). Disaster management: A disaster managers' handbook. Manila: Asian Development Bank Publications.

Clegg, S. (1981). Organization and Control. Administrative Science Quarterly, 26(4), 545562.

Clegg, S. (2020). Management of climate crisis and planetary boundaries through eco taxation. Manage Magazine. Retrieved from https://managemagazine.com/articlebank/strategic-management-article-bank/management-of-climate-crisis-andplanetary-boundaries-eco-taxation/

Clegg, S. R. (2010). Editor's introduction: Directions in organization studies. In S. Clegg (Ed.), Sage Directions in organization studies (pp. xxi-xcvii). Los Angeles: Sage.

Clegg, S. R., Maclean, M., Harvey, C., \& Suddaby, R. (2021). At the intersection of theory and history: A research agenda for historical organization studies. In M. Maclean, C. Harvey, R. Suddaby \& S. R. Clegg (Eds.), Historical organization studies: Advancing new directions for organizational research. London: Routledge.

Collier, S. J., \& Lakoff, A. (2008). Distributed preparedness: the spatial logic of domestic security in the United States. Environment and Planning D: Society and Space, 26(1), $7-28$. 
Collier, S. J., \& Lakoff, A. (2015). Vital Systems Security: Reflexive Biopolitics and the Government of Emergency. Theory, Culture \& Society, 32(2), 19-51.

Cronstedt, M. (2002). Prevention, preparedness, response, recovery - an outdated concept? Australian Journal of Emergency Management, 17(2), 10-13.

Cunha, M. P., Clegg, S. R., \& Kamoche, K. (2006). Surprises in Management and Organization: Concept, Sources and A Typology. British Journal of Management, 17(4), 317-329.

Cunha, M. P., Rego, A., Silva, Á. F. d., \& Clegg, S. (2015). An institutional palimpsest? The case of Cambodia's political order, 1970 and beyond. Journal of Political Power, $8(3), 431-455$.

Dean, M. (2010). Power at the heart of the present: Exception, risk and sovereignty. European Journal of Cultural Studies, 13(4), 459-475.

Deming, W. E. (2000). The new economics: For industry, government, education (2nd ed.). Cambridge: The MIT Press.

Department of Defence. (1983). The current state of natural disaster/civil defence planning in Australia. In D. Ball \& J. O. Langtry (Eds.), Civil defence and Australia's security in the nuclear age (pp. 110-121). Canberra, Sydney: Strategic and Defence Studies Centre, George Allen \& Unwin.

Deville, J., \& Guggenheim, M. (2018). From preparedness to risk: from the singular risk of nuclear war to the plurality of all hazards. The British Journal of Sociology, 69(3), 799-824.

Deville, J., Guggenheim, M., \& Hrdličková, Z. (2014). Concrete governmentality: shelters and the transformations of preparedness. The Sociological Review, 62, 183-210.

Douglas, M. (1982). Essays in the sociology of perception. London: Routledge \& Kegan Paul, published in co-operation with the Russell Sage Foundation. 
RUNNING HEAD: The historical embeddedness of organizational paradoxes

Douglas, M. (2001). Dealing with uncertainty. Ethical Perspectives, 8(3), 145-155.

du Gay, P. (2006). Machinery of government and standards in public service: teaching new dogs old tricks -- Texts reviewed. Economy and Society, 35(1), 148 - 167.

du Gay, P., \& Vikkelsø, S. (2012). Reflections: On the Lost Specification of 'Change'. Journal of Change Management, 12(2), 121-143.

Dwyer, A. (2006). Cyclone Tracy and Whitlam's 'new' federalism: implications for the management of natural disasters in Australia. The Australian Journal of Emergency Management, 21(3), 41-46.

Dwyer, G., \& Hardy, C. (2016). We have not lived long enough: Sensemaking and learning from bushfire in Australia. Management Learning, 47(1), 45-64.

Dwyer, G., Hardy, C., \& Maguire, S. (in press). Post-Inquiry Sensemaking: The Case of the 'Black Saturday’ Bushfires. Organization Studies.

Dynes, R. R. (1994). Community emergency planning: False assumptions and inappropriate analogies. International Journal of Mass Emergencies and Disasters, 12(2), 141-158.

EMA-AEMI. (2015). Australian Emergency Management Institute embarks upon new chapter. Australian Journal of Emergency Management, 30(1), 62.

Evans-Pritchard, E. E. (1937). Witchcraft, oracles and magic among the Azande. Oxford: The Clarendon Press.

Foucault, M. (1986). Kant on Enlightenment and revolution. Economy and Society, 15(1), 8896.

Gabriel, P. (2003). The development of municipal emergency management planning in Victoria, Australia. The Australian Journal of Emergency Management, 18(2), 74-80. 
Greenwood, R., Suddaby, R., \& Hinings, C. R. (2002). Theorizing Change: The Role of Professional Associations in the Transformation of Institutionalized Fields. The Academy of Management Journal, 45(1), 58-80.

Hahn, T., \& Knight, E. (2019). The ontology of organizational paradox: A quantum approach. Academy of Management Review.

Hällgren, M., Rouleau, L., \& de Rond, M. (2018). A Matter of Life or Death: How Extreme Context Research Matters for Management and Organization Studies. Academy of Management Annals, 12(1), 111-153.

Hardy, C., \& Maguire, S. (2016). Organizing risk: Discourse, power, and "riskification". Academy of Management Review, 41(1), 80-108.

Hardy, C., \& Maguire, S. (2020). Organizations, Risk Translation, and the Ecology of Risks: The Discursive Construction of a Novel Risk. Academy of Management Journal, 63(3), 685-716.

Hardy, C., Maguire, S., Power, M., \& Tsoukas, H. (2020). Organizing Risk: Organization and Management Theory for the Risk Society. Academy of Management Annals.

Hasluck, P. (1952). The government and the people, 1939-1941. Canberra: Australian War Memorial.

Heikkurinen, P., Clegg, S., Pinnington, A. H., Nicolopoulou, K., \& Alcaraz, J. M. (2019). Managing the Anthropocene: Relational Agency and Power to Respect Planetary Boundaries. Organization \& Environment.

Hilgartner, S. (1992). The social construction of risk objects: Or, how to pry open networks of risk. In J. F. Short \& L. B. Clarke (Eds.), Organizations, uncertainties, and risk (pp. 39-53). Boulder: Westview Press.

Hodges, A. (1999). Emergency management: then, now and the future. National Emergency Response, 14(1), 17-19. 
Islam, G. (2016). Rituals in organizations: Rupture, repetition and the institutional event. In R. A. Mir, H. Willmott \& M. Greenwood (Eds.), The Routledge companion to philosophy in organization studies (pp. 542-549). London: Routledge.

Jones, R. T. (1995a). Civil defence in Australia, 1940s to 1990s: A case study in Federal/State politics and public administration, Part 1. National Emergency Response, 10(1), 32-36.

Jones, R. T. (1995b). Civil defence in Australia, 1940s to 1990s: A case study in Federal/State politics and public administration, Part 2. National Emergency Response, 10(2), 27-36.

Jones, R. T. (2005). In Profile: Roger Jones. The Australian Journal of Emergency Management, 20(1), 55-57.

Kessler, O., \& Daase, C. (2008). From Insecurity to Uncertainty: Risk and the Paradox of Security Politics. Alternatives, 33(2), 211-232.

Knight, F. H. (1921). Risk, Uncertainty, and Profit. New York: Houghton Mifflin.

Lamont, B., \& He, T. (2020). Why prescribed burns don't stop wildfires. Sydney Morning Herald. Retrieved from https://www.smh.com.au/environment/climate-change/whyprescribed-burns-don-t-stop-wildfires-20200122-p53tl9.html

Maclean, M., Harvey, C., \& Clegg, S. R. (2016). Conceptualizing historical organization studies. Academy of Management Review, 41(4), 609-632.

Maguire, S., \& Hardy, C. (2013). Organizing Processes and the Construction of Risk: A Discursive Approach. Academy of Management Journal, 56(1), 231-255.

McCarthy, J. M. (1971). Australia and Imperial Defence: Co-operation and Conflict 19181939. Australian Journal of Politics \& History, 17(1), 19-32.

Meyer, J. W., \& Bromley, P. (2013). The Worldwide Expansion of "Organization". Sociological Theory, 31(4), 366-389. 
Mutch, A. (2018). Practice, Substance, and History: Reframing Institutional Logics. Academy of Management Review, 43(2), 242-258.

National Governors' Association. (1979). Comprehensive emergency management: A governor's guide. Washington, D.C.: Center for Policy Research.

Natural Disasters Organisation. (1989). Commonwealth counter-disaster concepts and principles, Australian Counter Disaster Handbook (Vol. 1). Canberra: Natural Disasters Organisation.

Osborne, P. (2015). Out of Sync: Tomba's Marx and the Problem of a Multi-layered Temporal Dialectic. Historical Materialism, 23(4), 39.

Parliament of Victoria. (2010). Victorian Bushfires Royal Commission. Final Report: Summary. (No. 332, Session 2006-2010). Retrieved from http://www.royalcommission.vic.gov.au/

Perrow, C. (1984). Normal accidents: living with high-risk technologies. New York: Basic Books.

Pierides, D., \& Woodman, D. (2012). Object-oriented sociology and organizing in the face of emergency: Bruno Latour, Graham Harman and the material turn. The British Journal of Sociology, 63(4), 662-679.

Power, M. (2007). Organized uncertainty: designing a world of risk management. New York: Oxford University Press.

Power, M. (2016). Riskwork: Essays on the organizational life of risk management (First edition. ed.). Oxford: Oxford University Press.

Pusey, M. (1991). Economic rationalism in Canberra: A nation-building state changes its mind. Cambridge: Cambridge University Press.

Reay, T., \& Hinings, C. R. (2009). Managing the Rivalry of Competing Institutional Logics. Organization Studies, 30(6), 629-652. 
Salter, J. (1997). Risk Management in a Disaster Management Context. Journal of Contingencies and Crisis Management, 5(1), 60-65.

Schad, J., \& Bansal, P. (2018). Seeing the Forest and the Trees: How a Systems Perspective Informs Paradox Research. Journal of Management Studies, 55(8), 1490-1506.

Smith, W. K., \& Lewis, M. W. (2011). Toward a Theory of Paradox: A Dynamic equilibrium Model of Organizing. Academy of Management Review, 36(2), 381-403.

Smith, W. K., Lewis, M. W., Jarzabkowski, P., \& Langley, A. (2019). Introduction: The paradoxes of paradox. In W. K. Smith, M. W. Lewis, P. Jarzabkowski \& A. Langley (Eds.), The Oxford handbook of organizational paradox (pp. 1-24). Oxford: Oxford University Press.

The Age. (1955, Thursday 20 January). Commonwealth buys Macedon Golf Club: To be our first Civil Defense School. Retrieved from http://news.google.com/newspapers?id=rLUUAAAAIBAJ\&sjid=8MQDAAAAIBAJ $\& p g=6070 \% 2 \mathrm{C} 2565247$

The Sydney Morning Herald. (1949, Monday 26 September). Civilian aid in defence. Retrieved from http://nla.gov.au/nla.news-article18131350

Thornton, P. H., Ocasio, W., \& Lounsbury, M. (2012). The institutional logics perspective: A new approach to culture, structure and process. Oxford: Oxford University Press.

Tolhurst, K. (2019). Black Saturday: Have we fixed a flawed system? Pursuit. Retrieved from https://pursuit.unimelb.edu.au/articles/black-saturday-have-we-fixed-a-flawedsystem

Tomba, M. (2013). Marx's temporalities. Leiden: Brill.

Tsoukas, H. (1997). The tyranny of light: The temptations and the paradoxes of the information society. Futures, 29(9), 827-843. 
Tsoukas, H. (2005). Complex knowledge: studies in organizational epistemology. New York: Oxford University Press.

Tuckermann, H. (2019). Visibilizing and Invisibilizing Paradox: A process study of interactions in a hospital executive board. Organization Studies, 40(12), 1851-1872.

van Loon, J. (2014). Remediating risk as matter-energy-information flows of avian influenza and BSE. Health, Risk \& Society, 16(5), 444-458.

Vardenga, R. (1978). Civil defence in Australia: An outline history. Department of Defence.

Weick, K. E. (1993). The Collapse of Sensemaking in Organizations: The Mann Gulch Disaster. Administrative Science Quarterly, 38(4), 628-652.

Whitlam, G. (1972). It's time for leadership: Australian Labor Party Policy Speech, Blacktown Civic Centre. Parramatta: Whitlam Institute.

Wigley, P. G. (1977). Canada and the transition to Commonwealth: British-Canadian relations, 1917-1926. Cambridge: Cambridge University Press.

\section{NOTES}

\footnotetext{
${ }^{\mathrm{i}}$ One consequence is that historical narration does not easily admit of brevity; the story must be fully documented, as we sought to do in our narrative.

ii As outlined in the Australia/New Zealand Risk Management Standard AS/NZS 4360, released in 1995 and later updated in 1999, 2004 and 2009.

iii On this point, Mutch (2018, p. 251) makes reference to Osbourne's (2015) critique of Tomba's (2013) reformulation of Marx in order to think about the concept of institutional logics in a manner that better accounts for the time frame of historians. In so doing, he points to Tomba's use of strata and sedimentation as a metaphor. Developing our less metaphorical version of this argument is beyond the scope of our article, however we would agree with Mutch that doing so would involve a return to Henri Bergson's philosophy of time.
} 
RUNNING HEAD: The historical embeddedness of organizational paradoxes

iv In the State of Victoria, a new professional emergency service agency, Fire Rescue Victoria, is about to launch and will replace the Metropolitan Fire Brigade. The new agency will be staffed by career firefighters from the Country Fire Authority (CFA) and the Melbourne Fire Brigade. It subsumes all professional and volunteer stations and staff. Volunteer firefighters have been excluded from government consultations and the CFA chief officer, Steve Warrington, has tendered his resignation. Warrington has on previous occasions demonstrated reflexive awareness of the limitations of the CFA. This same reflexive awareness does not extend to the professionalized emergency management organizations and their staff; unlike volunteer firefighting, risk management and its technologies are seen by professional emergency managers and government officials as exactly the kind of panacea we have identified as similarly ritualistic. The emergency management paradox is invisible from inside a world that is saturated with risk and its calculative knowledge practices.

${ }^{\mathrm{v}}$ In a measure of their significance, a comedian Celeste Barber, established a bushfire fund raiser on Facebook. The target was to raise AUD\$30,000; it actually raised AUD\$51 million which will be distributed by the Trustee for NSW Rural Fire Service (RFS) and Brigades Donation Fund; thus, this organization, established as a state body, is now being funded by donation as well as by the state. 